\title{
Qualitative Analysis of Peptides and Biological Activities of Allexis cauliflora (Violaceae) Leaves
}

\author{
Y.O. Nganso Ditchou ${ }^{1,3, *}$, D. Soh',3, E.Z. Nkwengoua Tchouboun³, E.M. Tchana Satchet ${ }^{3}$, H. Mamoudou4, B. Nyasse ${ }^{3}$ \\ ${ }^{1}$ Department of Chemistry, Faculty of Science, University of Maroua, P.O Box 814, Maroua, Cameroon. \\ ${ }^{2}$ Department of Chemistry, Higher Teachers Training College, University of Bamenda, P.O Box 39, Bambili, Bamenda, Cameroon. \\ ${ }^{3}$ Laboratory of Medicinal Chemistry \& Pharmacognosy, Department of Organic Chemistry, Faculty of Science, University of Yaoundé I, P.o Box 812 Yaoundé, \\ Cameroon. \\ ${ }^{4}$ Department of Biological Sciences, Faculty of Science, University of Maroua, P.O Box 814, Maroua, Cameroon.
}

\section{ARTICLE DETAILS}

Article history:

Received 15 June 2020

Accepted 11 August 2020

Available online 17 September 2020

\section{Keywords:}

Allexis cauliflora

Biological Activities

Violaceae

Peptides

\begin{abstract}
A B S T R A C T
Allexis cauliflora is a Cameroonian medicinal plant belonging to the violaceae family. It is used in traditional medicine to treat fever, syphilis and malaria. The aim of this study is to screen the peptides from the leaves of Allexis cauliflora and assess their biological activities. Previous studies have demonstrated antimicrobial properties of this plant. These properties have been mainly attributed to phenolic compounds. However, other plant defense molecules, such as antimicrobial peptides, may be present. In this work, we studied peptide extracts from the leaves of Allexis cauliflora. This plant has also been examined to determine its antimicrobial activities and its minimum inhibitory concentrations against bacteria pathogenic to humans and fungi using the agar well diffusion method. The corresponding concentration value antilog was taken as the minimum inhibitory concentration value. All values of test results were expressed as triple means, mean \pm standard deviation. The extract from the leaves of this plant has shown antimicrobial activity against the bacterial and fungal pathogens studied. The phytochemical screening carried out showed the presence of flavonoids and triterpenes. Based on the results obtained, the medicinal value of this plant could be attributed to the presence of secondary metabolites in traditional medicinal plants.
\end{abstract}

\section{Introduction}

Antibiotics are used in both humans and animals to prevent, treat and cure diseases caused by bacteria. Bacterial resistance to antibiotics is of great concern at the start of this millennium. With the commercialization of penicillin in 1941, and then the first families of antibiotics, resistant bacterial strains appeared. During in the past two decades, more and more cases of bacterial multidrug resistance conventional antibiotics have been identified [1]. At the level of all microorganisms, these multi-resistances are linked to several factors such as the misuse of antibiotics in agriculture and livestock, the use inappropriate antibiotics in the clinic and more specifically, modifications of the microorganism itself [1]. Faced with this alarming situation, it is urgent to find new treatments against which bacteria do not still developed of resistance. To this end, various avenues are explored by researchers: (1) those of bacteriophages which can confer genes sensitivity to bacteria, (2) those of therapeutic combinations with activity synergistic, (3) those from extracts of pharmacopoeia plants from different countries, (4) those of antimicrobial peptides (AMPs), poly-Nsubstituted peptoids or glycines are a class of peptidomimetics whose side chains are attached to the nitrogen atom of the peptide backbone and synthetic molecules are obtained from PAMs [2]. In Africa, plants are also used in an ancestral way. Today, faced with the emergence of new infectious diseases and neurological and many resistant strains of pathogens, plants medicines are an alternative. So, more and more scientists are interested in plants and try to isolate the active ingredients $[3,4]$.

The medicinal properties of plants, due to their chemical composition, can be explained by the fact that plants synthesize primary metabolites (proteins, lipids, and carbohydrates) for their existence and those of organisms which feed on it as well as secondary metabolites intended to protect them against attacks caused by fungi, bacteria, animals or other plants. It is in this second group of metabolites that the Active molecules [5]. Based on the above, this work carried out on a plant Allexis cauliflora of genus Allexis.

\section{*Corresponding Author:nganso_yves@yahoo.fr(Y.O. Nganso Ditchou)}




\section{Experimental Methods}

\subsection{Preparation of Extracts}

The plant material was washed, air dried and then coarsely powdered. 18 grams of the powdered roots samples were extracted sequentially using Soxhlet's method for $72 \mathrm{~h}$ at a temperature not exceeding the boiling point of the solvent into $250 \mathrm{~mL}$ of methanol for extract preparation. Resulting extracts was concentrated in vacuum to dryness using a rotary evaporator. Each powder was weighed and dissolved in the methanol solvents used for extraction separately and stored at $4{ }^{\circ} \mathrm{C}$.

\subsection{Antimicrobial Activity}

One of the standard assay methods for testing antimicrobial activity is the Kirby-Bauer method [24], also referred to as the disc diffusion method. A selective culture media were prepared in the antimicrobial assay container and subsequently streaked uniformly with the selected test microorganisms.

\subsubsection{Test Organisms}

A Kirby-Bauer [24] technique was used to screen the antimicrobial activity for the methanolic leaves of Allexis cauliflora. The bacterial cultures of Gram-positive (Aeromonas hydrophila, Escherichia coli MTCC739, Flavobacterium sp, Pseudomonas aeruginosa MTCC424, Salmonella typhi murium and Yersinia enterocolitica) and Gram-negative (Bacillus cereus MTCC430, Listeria monocytogenes, Staphylococcus aureus MTCC3381) bacteria; the fungal cultures of Aspergillus flavus, Aspergillus fumigatus MTCC343, Aspergillus oryzae, Candida albicans MTCC227 and Pencillium notatum were used to test the antimicrobial activity.

\subsubsection{Preparation of Inoculum}

To prepare the bacterial and fungal inoculums from each of the microorganisms, a loopful of each test organisms was taken and subsequently sub-cultured into separate test tubes containing the nutrient agar broth. Then, the tubes were subjected to incubation for $24 \mathrm{~h}$ at $37^{\circ} \mathrm{C}$, the obtained broth with microorganisms was standardized to have a uniform population density of microorganisms in microbial culture laboratory.

\subsection{Screening for Antibacterial Activity}

The antibacterial activity of Allexis cauliflora was assayed by a modification of agar well diffusion method $[6,7]$. Different concentrations of the extracts were prepared by reconstituting with dimethyl sulphoxide (DMSO). The test organisms were maintained on agar slants were recovered for testing by inoculating into nutrient broth and incubated at $37{ }^{\circ} \mathrm{C}$ in a shaker at $180 \mathrm{rpm}$. The culture of each microorganism was inoculated in plates in nutrient agar and spread evenly using sterile glass spreader. Test extracts were incorporated into the wells made by sterile 5 $\mathrm{mm}$ size borer in media and different concentration of methanolic extracts were added and water alone as a control. Plates were incubated at $37^{\circ} \mathrm{C}$ and after $24 \mathrm{~h}$, the zone of inhibition of methanolic extract, standard control were measured using transparent ruler. Antibacterial screening was done in triplicates.

\subsection{Screening for Antifungal Activity}

Antifungal activity of all various extracts was studied against two fungal strains by the agar well diffusion method $[25,26]$. The fungal isolates were allowed to grow on a potato dextrose agar at $25^{\circ} \mathrm{C}$ until they sporulated. The fungal spores were harvested after sporulation by pouring a mixture of sterile distilled water. The fungal spores suspension was evenly spread on plate using sterile glass spreader. Wells were then bored into the agar media using sterile $5 \mathrm{~mm}$ cork borer and the wells filled with the solution of the extract and water alone as a control. The plates were allowed to stand on a laboratory bench for $1 \mathrm{~h}$ to allow for proper diffusion of the extract into the media. Plates were incubated at $25^{\circ} \mathrm{C}$ for $96 \mathrm{~h}$ and later observed for zones of inhibition of methanolic extract, standard control and measured using transparent ruler. Antifungal screening was done in triplicates.

\subsection{Minimum Inhibitory Concentration}

\subsubsection{Antimicrobial Tests with Plant Extracts}

Organisms were subcultured on nutrient agar, followed by incubation for $24 \mathrm{~h}$ at $37^{\circ} \mathrm{C}$. Inoculum was prepared by transferring several colonies of microorganisms to sterile nutrient broth [8]. The suspensions were mixed for $15 \mathrm{~s}$ and incubated for $24 \mathrm{~h}$ at $37^{\circ} \mathrm{C}$. Required volume of suspension culture was diluted to match the turbidity of 0.5 Mc Farland 
appropriate fractions were collected and the ACN was evaporated on a Speedvac centrifuge. The fractions were then analyzed by reverse phase HPLC (RP) (Waters Associates, Milford, MA, USA) on a BEH C18 Water Corp XBridge ${ }^{T M}$ column $(100 \times 4.6 \mathrm{~mm}, 3.5 \mu \mathrm{m})$. Waters Associates, Milford, MA, USA) using a gradient of 0 to $70 \%$ ACN, water containing $0.05 \%$ TFA as solvent $\mathrm{A}$ and $\mathrm{ACN}$ containing $0.05 \% \mathrm{TFA}$ as solvent $\mathrm{B}$, at a flow rate of $1 \mathrm{~mL} / \mathrm{min}$ for 8 mins.

\subsubsection{Mass Spectrometry Analysis for Peptide Identification}

The mass spectra of each ACN fraction were performed in a Microflexassisted matrix desorption laser desorption flight time mass spectrometer (Bruker Daltonics Inc., Billerica, MA, USA). The 40\% ACN fraction was prepared for ESI MS/MS sequencing. Indeed the extract was reduced (dithiothreitol), alkylated with iodoacetamide and enzymatically digested using trypsin or endo-GluC (Sigma-Aldrich and Promega Corp., Madison, WI, USA) respectively [28]. Proteolysed samples were examined in an LCMS-MS system consisting of an Agilent 1100 HPLC (Agilent Technologies Inc., Santa Clara, California, USA) coupled to an ESI-TRAP ion trap mass spectrometer Esquire 4000 (Bruker Daltonik GmbH, Bremen, Germany). For Chromatogram Analysis and LC-ESI-MS-MS, Data Analysis Version.

\subsection{Qualitative Phytochemical Analysis}

$0.08 \mathrm{~g} / \mathrm{mL}$ of extract was subjected to preliminary phytochemical screening following standard methods for detection of the constituents' viz. steroids, tannins, saponins, alkaloids, proteins, anthocyanins, coumarin, carbohydrates, flavonoids, leucoanthocyanins, phlobatannins, terpenoids and phenols [29-31].

\subsection{Determination of Total Phenolic Content (TPC)}

The concentration of TPC was measured using a UV spectrophotometer, based on oxidation/reduction reaction [11] using Folin-Ciocalteu reagent [30]. To $500 \mu \mathrm{L}$ of diluted extracts $(10 \mathrm{mg}$ in $10 \mathrm{~mL}$ solvent), $2.5 \mathrm{~mL}$ of Folin-Ciocalteu reagent (diluted 10 times with distilled water) and $2 \mathrm{~mL}$ of $\mathrm{Na}_{2} \mathrm{CO}_{3}(7.5 \%)$ were added. The samples were incubated for $5 \mathrm{~min}$ at 50 ${ }^{\circ} \mathrm{C}$ and then cooled. Distilled water $(500 \mu \mathrm{L})$ was used as a negative control for the experiment. The absorbance of the standard gallic acid solution $(0.5 \mathrm{mg} / \mathrm{mL})$ was measured using $500 \mu \mathrm{L}$ of $50,100,150,200,250$ and 300 $\mu \mathrm{g} / \mathrm{mL}$ methanolic gallic acid solutions. All determinations were performed in triplicate and a standard curve was established. The total phenol value was obtained from the regression equation: $\mathrm{y}=0.0106 x+$ 0.1246 and expressed as $\mathrm{mg} / \mathrm{g}$ gallic acid equivalent using the formula, $\mathrm{C}$ $=\mathrm{cV} / \mathrm{M}$; where $\mathrm{C}=$ total content of phenolic compounds in $\mathrm{mg} / \mathrm{g} \mathrm{GAE}, \mathrm{c}=$ the concentration of gallic acid $(\mu \mathrm{g} / \mathrm{mL})$ established from the calibration curve, $\mathrm{V}=$ volume of extract $(0.5 \mathrm{~mL})$ and $\mathrm{m}=$ the weight of pure plant methanolic extract $(0.05 \mathrm{~g})$.

\section{Results and Discussion}

\subsection{Collection of Allexis cauliflora Leaves}

The leaves of Allexis cauliflora were collected at the Elephant Mountain in Kribi in the southern province in July 2007 by Mr. Nana from the National Herbarium. A sample was deposited at the National Herbarium of Yaoundé in Cameroon under the number (HNC 18374).

\subsection{Identification of Peptides from Allexis cauliflora Leaves}

Peptides have generally shown antimicrobial activity against various human pathogens and therefore appear to be promising antibiotic compounds with important biotechnological applications [32]. In this study, the presence of peptides in the leaves of Allexis cauliflora, a medicinal plant used in Cameroon, has been demonstrated. The experimental procedure for extracting peptides is illustrated in Fig. 2.

The strategy consisted of dipping the plant material in a $\mathrm{DCM}-\mathrm{MeOH}$ mixture $(1: 1, \mathrm{v} / \mathrm{v})$ for 24 hours at room temperature, a procedure widely used for the extraction of the peptide [33]. However, after the addition of water, the aqueous layer contained large amounts of polyphenols $(0.987$ $\mathrm{mg} / \mathrm{mL}$ ). Thus, the polyamide resin must be used for their removal, because a strong hydrogen bond occurs between the polyphenols and the polyamide, but the peptides are not retained on this column support [3436]. Fig. 3 refers to the presence of cyclotide peptides in the leaves of Allexis cauliflora. Nevertheless, the structure which is adopted by the cyclotides prohibits the analysis of direct fragmentation. Thus, a partial primary structure of the peptides has been determined by enzymatic fragmentation of reduced proteins and alkylated peptides because, these chemical modifications necessary to obtain precursor ions, are subject to MS/MS sequencing [37].

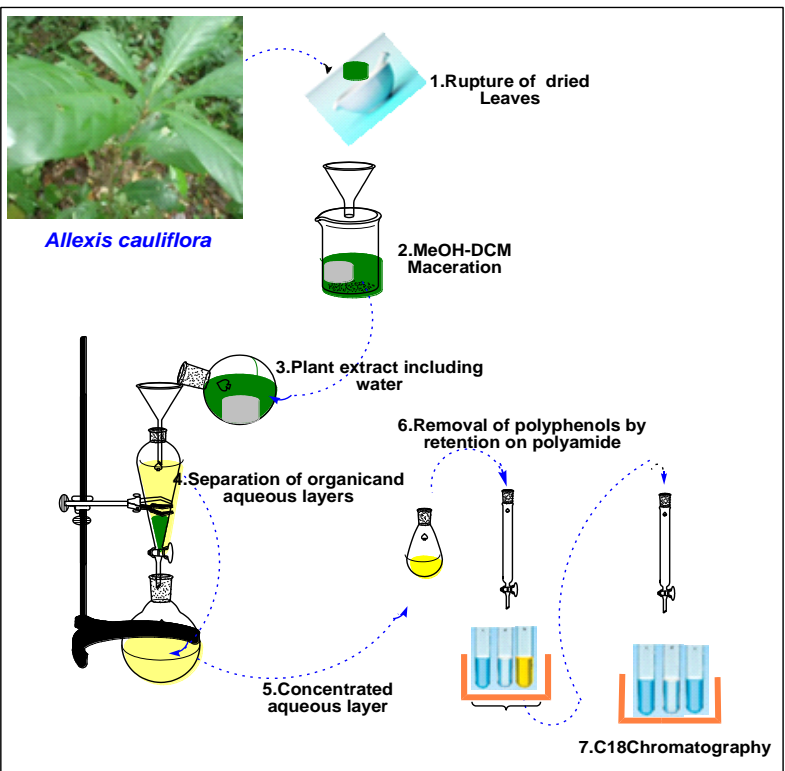

Fig. 2 Schematic representation of the major steps for the peptide extraction procedure

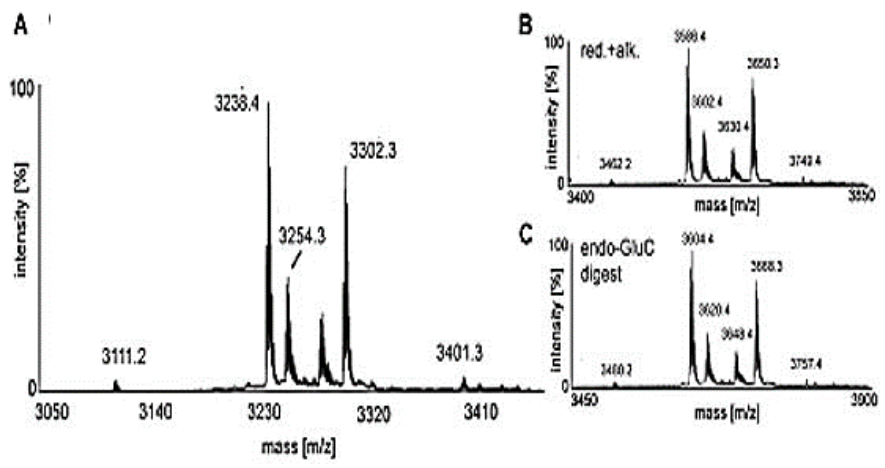

Fig. 3 Characterization of peptide extracts from Allexis cauliflora leaves

The alkylated peptides were then cleaved with trypsin or Glu-C endoproteinase, and the resulting peptide fragments were identified by mass ESI-MS/MS spectrometry using Mascot and PEAKS servers. The characterization of the identified peptides are presented in Table 1. From the analysis of MS/MS data, the identification of a peptide as Chasatide C10 is based on a concordance with a small part of the sequence described in the literature. on this subject $(5 / 29=$ sequence of $17 \%$ coverage $)$, but this identification was supplemented by MALDI-MS data where the signal $\mathrm{m} / \mathrm{z}$ 3212.107 was detected and presented an error of $-55.7 \mathrm{ppm}$ compared to the $\mathrm{m} / \mathrm{z}$ expected for this cyclotide. Likewise, from MS/MS data, a peptide was identified as Glopa $\mathrm{E}$ based on coincidence with part of the sequence described for it (sequence coverage $6 / 30=20 \%$ ). In addition, MALDI-MS data suggests the presence of a peptide with an $\mathrm{m} / \mathrm{z} 3228.618$ close to the expected value for Glopa $\mathrm{E}$ of $\mathrm{m} / \mathrm{z}$ 3227.398. In both cases, it would be necessary to detect the disappearing tryptic peptide to confirm the complete sequence. The identification of tryptic peptides such as cyclotides Caripe 4 and Vaby $\mathrm{C}$ was based on the sequence correspondence of 59 and $45 \%$ respectively, determined from the analysis of MS/MS data. Finally, identification as Phyb A was based on the $83 \%$ coincidence of the sequence. In summary, the MALDI-MS data show that the peptides detected are within the $\mathrm{m} / \mathrm{z}$ range described for the cyclotides. While the MS/MS data showed partial coincidence with known cyclotide sequences.

Table1 Peptides presents in the leaves of Allexis cauliflora

\begin{tabular}{lll}
\hline Sequence detected & $\begin{array}{l}\text { Peptides rich in } \\
\text { Cysteine }\end{array}$ & Family \\
\hline GEYCGESCYLIPCFTPGCYCVSRQCVNK & $\begin{array}{l}\text { Chassatide_C10 } \\
\text { (Chassalia_chartacea) }\end{array}$ & Cyclotide \\
GIPCAESCVWIPCTVKMLCGSCKDKVCYN & $\begin{array}{l}\text { Glopa E } \\
\text { (Gloesospermum } \\
\text { pauciflorum hekking) } \\
\text { Caripe } 4 \text { (Carapichea } \\
\text { Ipecacuanha })\end{array}$ & Cyclotide \\
LICSSTCLRIPCSPRCTVRHHICYLN & $\begin{array}{l}\text { Vaby C (Viola } \\
\text { abyssinica }) \\
\text { Phyb_A (Petunia } \\
\text { hybrida) }\end{array}$ & Cyclotide \\
GIGCGESCVWIPCVSAAIGCSCSNKICYRN & Cyclotide \\
& &
\end{tabular}




\subsection{Biological Activities}

Plants are recognized as important sources of secondary metabolites used in traditional medicine to treat various diseases [38]. In this study, the antibacterial activity of methanolic extracts from the leaves of Allexis cauliflora was evaluated. The extracts were screened against Grampositive and Gram-negative bacteria. The results were compared to standard drugs such as gentamycin for bacterial cultures. The inhibition zone was measured and tabulated (Table 2). Fungi can damage structures and decorations in buildings and are also responsible for the quality of their indoor air [39]. The antifungal activity was evaluated by the method of diffusion on agar wells. The extract showed significant activity against all fungi tested compared to the standard drug, nystatin $(10 \mu \mathrm{g} / \mathrm{disc})$. The reason for the difference in sensitivity between Gram-positive and Gramnegative bacteria could be attributed to the differences morphological between these microorganisms, Gram-negative pathogens having an external phospholipid membrane carrying the structural components of the lipopolysaccharide. This makes the cell wall impermeable to lipophilic solutes, while the porins provide a selective barrier to hydrophilic solutes with an exclusion limit of around $600 \mathrm{Da}$. Gram-positive bacteria should be more likely to have only an outer layer of peptidoglycone, which is not an effective barrier to permeability [40]

Table 2 Minimum inhibitory concentrations results

\begin{tabular}{lllll}
\hline Micro organisms & \multicolumn{4}{c}{ Minimum inhibitory concentration $(\mu \mathrm{g} / \mathrm{mL})$} \\
\cline { 2 - 5 } & 50 & 100 & 150 & Std. Drug \\
\hline Bacteria & 13 & 10 & 11 & Gentamycin \\
Aeromonas hydrophila & 12 & 10 & 13 & 17 \\
Escherichia coli & 10 & 10 & 12 & 20 \\
Flavobacterium sp. & 12 & 11 & 12 & 19 \\
Pseudomonas aeruginosa & 23 & 12 & 10 & 18 \\
Salmonella typhimurium & 9 & 9 & 10 & 24 \\
Yersinia enterocolitica & 12 & 13 & 15 & 28 \\
Bacillus cereus & 15 & 19 & 18 & 32 \\
Listeria monocytogenes & 11 & 14 & 15 & 28 \\
Staphylococcus aureus & & & & Nystatin \\
Fungus & 12 & 12 & 16 & 08 \\
Aspergillus flavus & 11 & 10 & 14 & 08 \\
Aspergillus fumigatus & 11 & 11 & 12 & 08 \\
Aspergillus oryzae & 14 & 13 & 15 & 14 \\
Candida albicans & 17 & 11 & 15 & 12 \\
Penicillium notatum & & &
\end{tabular}

\subsection{Phytochemical Screening}

\subsubsection{Qualitative Phytochemical Analysis and Percentage Yields}

Yields obtained from leaves, stems and roots with water ranged from 39.44 to $41.67 \% \mathrm{w} / \mathrm{w}$, while those with ethanol ranged from 15.20 to $26.08 \% \mathrm{p} / \mathrm{p}$. The results of the phytochemical screening tests (strong, weak and negative) obtained from water and $70 \%$ ethanol extracts from the roots are presented in Table 3.

Table 3 The results of the phytochemical screening tests (strong, weak and negative) obtained from the water and $70 \%$ ethanol extracts of the leaves of Allexis cauliflora

\begin{tabular}{|c|c|c|c|}
\hline \multicolumn{2}{|c|}{ Compounds } & Water Extract & Ethanol Extract \\
\hline \multicolumn{2}{|c|}{ 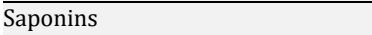 } & + & - \\
\hline \multicolumn{2}{|c|}{ Flavonoids } & ++ & ++ \\
\hline \multicolumn{2}{|c|}{ Proteins } & ++ & ++ \\
\hline \multicolumn{2}{|c|}{ Coumarins } & ++ & + \\
\hline \multicolumn{2}{|c|}{ Cardiac glycoside } & ++ & ++ \\
\hline \multicolumn{2}{|c|}{ Terpenoids } & ++ & + \\
\hline \multicolumn{2}{|c|}{ Phlobatannins } & - & - \\
\hline \multicolumn{2}{|c|}{ Steroids } & - & + \\
\hline \multicolumn{2}{|l|}{ Phenols } & + & - \\
\hline \multicolumn{2}{|l|}{ Tannins } & + & - \\
\hline \multicolumn{2}{|c|}{ Carbohydrates } & - & - \\
\hline \multirow[t]{3}{*}{ Alkaloids } & Mayer's reagent & - & - \\
\hline & Dragendorff's reagent & - & - \\
\hline & Wagner's reagent & - & - \\
\hline \multicolumn{2}{|c|}{ Leucoanthocyanins } & - & - \\
\hline \multicolumn{2}{|c|}{ Anthocyanins } & - & - \\
\hline \multicolumn{2}{|c|}{ Percentage yields (\% w/w) } & 39.44 & 15.20 \\
\hline
\end{tabular}

$++=$ Strong positive test,$+=$ Weak positive test,$-=$ Negative tests

The presence of flavonoids, saponins, coumarins, terpenoids in the aqueous and ethanol extracts of the leaves of Allexis cauliflora have been noted. Flavonoids are found in abundance in ethanol and aqueous extracts of the leaves. The tannins are present in the aqueous extract and not in the ethanol extract of the leaves of Allexis cauliflora. Glycosides are present in all extracts.

Table 4 Phenolic and flavonoid contents of the water and 70\% ethanol extracts from the leaves of Allexis cauliflora

\begin{tabular}{llllr}
\hline Plant parts & $\begin{array}{l}\text { Phenolic Content } \\
(\mathrm{mg} \pm \mathrm{SD})\end{array}$ & $\begin{array}{l}\text { GAE } \\
\text { (g of dry extract) }\end{array}$ & $\begin{array}{l}\text { Flavonoid content } \\
\text { (mg of QE/g of dry extract) } \pm \mathrm{SD}\end{array}$ \\
\cline { 2 - 5 } & Water & Ethanol & Water & Ethanol \\
\hline leaves & $1.97 \pm 0.1 a$ & $0.19 \pm 0.02 a$ & $0.023 \pm 0.01 a c$ & $0.042 \pm 0.01 a c$ \\
\hline
\end{tabular}

Data represents the mean $\pm S D \mathrm{mg}$ of Gallic acid equivalent per gram of dry weight $(\mathrm{mg}$ $G A E / g$ ) and quercetin equivalent per gram of dry weight ( $\mathrm{mg} Q \mathrm{QE} / \mathrm{g}$ ) of the extracts, $n=$ 3. Small letter a indicates statistically significant groups according to the t-test: TwoSample Assuming Equal Variance $(p<0.05)$. Non-significant groups are represented.

\subsubsection{Quantitative Phytochemical Analysis}

The total content of phenols and flavonoids in the three parts of the plant is shown in Table 4 . The amount of phytochemicals varies not only between leaves, stems and roots, but also depends on the use of water or the ethanol as an extractant. The highest phenolic content appeared in the leaves of the water and ethanol extracts followed by the stems and roots. The leaves had the highest total flavonoid content compared to the stems and roots.

\subsection{Total Flavonoid Content}

The absorbance values of quercetin and the standard calibration curve is illustrated in Fig. 4. The flavonoid content of aqueous extracts in terms of quercetin equivalent (the equation of the standard curve: $\mathrm{y}=0.0175 \mathrm{x}$ $0.0061, \mathrm{R}^{2}=0.9892$; Fig. 4 was found to be $0.025 \mathrm{mg} / \mathrm{g}$ for root extracts. In $70 \%$ ethanol extracts, the flavonoid content was $0.038 \mathrm{mg} / \mathrm{g}$ for the leaf.

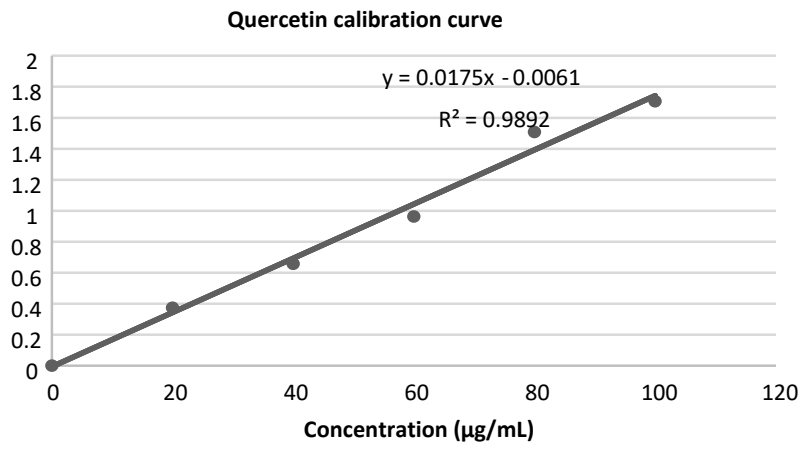

Fig. 4 Standard calibration curve for quantification of Flavonoid content

\subsection{Total Phenolic Content}

The absorbance of standard compound (gallic acid) at $\lambda \max =760 \mathrm{~nm}$ in Allexis cauliflora and standard calibration curve for the quantification of the total phenol content is presented in Fig. 5. This figure shows the content of total phenols which were measured by the Folin Ciocalteu reagent in terms of gallic acid equivalent (equation of the standard curve: $\mathrm{y}=0.0106 \mathrm{x}+0.1246, \mathrm{R}^{2}=0.9949$. The total phenol content aqueous extracts were found to be $1.91 \mathrm{mg} / \mathrm{g}$ of leaf extracts. In $70 \%$ ethanol extracts, the total phenol content was found to be $0.15 \mathrm{mg} / \mathrm{g}$

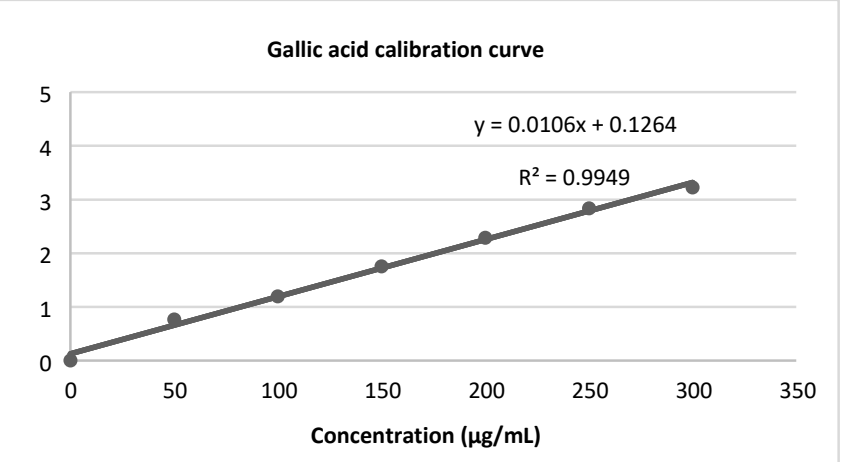

Fig. 5 Standard calibration curve for quantification of total phenolic content

\subsection{Discussion}

Antibiotics are chemicals produced by microorganisms or by chemical synthesis of molecules derived from natural compounds. They prevent the growth of other microorganisms and, in some cases, can destroy them. 
Given their broad antimicrobial spectrum, these molecules appear as interesting targets to be exploited for the improvement of animal health $[41,42]$. Here, this present work focused on the study of the antimicrobial activity of the peptide extract of the leaves of Allexis cauliflora against various Gram-negative bacterial pathogens that affect vegetable crops.

The analysis and characterization of bioactive plant compounds are important to determine their medicinal value. This study showed that pharmacologically active compounds such as terpenoids, flavonoids, steroids, cardiac glycosides, phenols and coumarins were present in the leaves of Allexis cauliflora (Table 3). Various chemicals have been used to extract bioactive compounds from plants. In this study, water and $70 \%$ ethanol showed differential extraction of certain compounds. Total phenolic compounds ranged from 1.91 to $3.59 \mathrm{mg} / \mathrm{g}$ of gallic acid equivalent for aqueous extracts and from 0.98 to $0.15 \mathrm{mg} / \mathrm{g}$ of gallic equivalent for ethanol extracts, the total flavonoid concentration varied from 0.47 to $0.025 \mathrm{mg} / \mathrm{g}$ quercetin equivalent for the aqueous extracts and from 0.66 to $0.038 \mathrm{mg} / \mathrm{g}$ quercetin equivalent for the ethanolic extracts. These data show that $70 \%$ ethanol and water extracts are less efficient for extraction. The activity of the peptide extract of the leaves of Allexis cauliflora was evaluated against Aeromonas salmonicida, Flavobacterium psychrophilum, Vibrio anguillarum and Vibrio ordalii, all Gram-negative bacterial pathogens found in vegetable crops in Cameroon. Analyzes on microplates have shown the ability of the extract to reduce the growth of all pathogens. The strongest antimicrobial effect was observed at a concentration of $100 \mu \mathrm{g} / \mathrm{mL}$ of the peptide extract.

\section{Conclusion}

An antimicrobial exploration of the extracts of the leaves of Allexis cauliflora was carried out to determine the identification of the antimicrobial compounds in this plant and also to determine their full spectrum of efficacy. The extract has shown antibacterial activity against certain types of microorganisms on which it has been used. Its antimicrobial property against certain microbes and the presence of secondary metabolites have potential to treat various infectious diseases. The presence of cysteine-rich peptides in the leaves of Allexis cauliflora has been determined and shows activity against various pathogens. Their antimicrobial activity has been shown to be linked to disruption of the bacterial cell membrane. The bioactive compounds reported in various extracts justify the medicinal activities of Allexis cauliflora which must be deepened and certain pharmacological active principles must be produced and validated in order to be used as a potential force in the health field for the treatment of infectious diseases.

\section{Acknowledgements}

The authors thank Mr. Nana Victor, a botanist at the National Herbarium of Cameroon for the collection of Allexis cauliflora and Mr. Mamoudou Hamadou, The Laboratory of Phytobiochemistry of Medicinal Plants, Department of Biological Sciences, Faculty of Science, University of Maroua for the antimicrobial tests.

\section{References}

[1] B.H. Normark, K. Normark, Evolution and spread of antibiotic resistance, J. Intern. Med. 252(2) (2002) 91-106.

[2] W. Witte, Impact of antibiotic use in animal feeding on resistance of bacterial pathogens in humans, CIBA Found Symp. 207 (1997) 61-71.

[3] D.J. Newman, G.M. Cragg, K.M. Snader, The influence of natural products upon drug discovery, Natural Prod. Rep. 17 (2000)175-285.

[4] J.Y. Chabrier, Medicinal plants and forms of use in herbal medicine, Doctoral Thesis, Pharmacological Faculty, Henri Poincare University, Frane, 2010.

[5] J. Ferrari, Contribution to the knowledge of the secondary metabolism of Thymelaeaceae and phytochemical investigation of one of them: Gnidia involucrata Steud.ex A. Rich, Doctoral thesis, University of Lausanne, Switzerland, 2002.

[6] J. Hutchinson, J.M. Dalziel, Flora of tropical East Africa, Glossary of bot nical terms, Reprinted from “The flora of West Africa. Revised by R.W.J. Keay, 2nd edition, Crown Agents for Oversea Government and Administration, Millbank, London S.W., 1954

[7] G. Achoundong, The African genus Allexis (Violaceae), A synoptic revision, National Herbarium, COUNTRY, 2010.

[8] G. Achoundong, J.M.Onana, Allexis zygomorpha (Violaceae): a new species from the littoral forest of Cameroon, Kew Bulletin. 53 (4) (1998) 1009-1010.

[9] V. Vukics, A. Kery, G.K. Bonn, A. Guttman, Major flavonoid components of heartsease (Viola tricolor L.) and their antioxidant activities, Anal. Bioanal. Chem. 390 (2008) 1917-1925.

[10] H.I. Moon, J.C. Jung, J. Lee, Antiplasmodial activity of triterpenoid isolated from whole plants of Viola genus from South Korea, Parasitol. Res. 100 (2007) 641644.
[11] A.N. Messi, J. Ngo Mbing, J.T. Ndongo, M.A. Nyegue, A. Tiabou Tchinda, et al., Phenolic compounds from the roots of Ochnas chweinfurthiana and their antioxidant and antiplasmodial activities, Phytochem. Lett. 17 (2016) 119125.

[12] Y.O.D. Nganso, I.E.W. Ngantchou, E. Nkwengoua, B. Nyasse, C. Denier, et al. Antitrypanosomal and cytotoxic activities of 22-hydroxyclerosterol, a new sterol from Allexis cauliflora (Violaceae), Scientia Pharmaceutica. 79 (2011) 137-144.

[13] G.A. Amang Angnoung, Y.O.D. Nganso, L. Meli, M.T.G. Mala Opono, New biflavonoid from the roots of Allexis cauliflora (Violaceae) and evaluation of antibacterial activities, Int. J. Curr. Adv. Res. 7(9) (2018) 15375-15378.

[14] M. Jabbari, B. Daneshfard, M. Emtiazy, A. Khiveh, M.H. Hashempur, Biological effects and clinical applications of dwarf elder (Sambucus ebulus L), A review, J. Evid. Based Complement. Altern. Med. 22 (2017) 996-1001.

[15] C. Krawitz, M.A. Mraheil, M. Stein, C. Imirzalioglu, E. Domann, S. Pleschka, T. Hain, Inhibitory activity of a standardized elderberry liquid extract against clinically-relevant human respiratory bacterial pathogens and influenza $\mathrm{A}$ and B viruses, BMC Complement. Altern. Med. 11 (2011) 16:1-6.

[16] R. Nawrot, J. Barylski, G. Nowicki, J. Broniarczyk, W. Buchwald, A. GozdzickaJózefiak, Plant antimicrobial peptides, Folia Microbiol. 59 (2014) 181-196.

[17] M. Pasupuleti, A. Schmidten, M. Malmsten, Antimicrobial peptides: key components of the innate immune system, Crit. Rev Biotechnol. 32(2) (2011) 143-171.

[18] J.P. Tam, S. Wang, K.H. Wong, W.L. Tan, Antimicrobial peptides from plants, Pharmaceut. 8 (2015) 711-757.

[19] N.L. Daly, K.J. Rosengren, D.J. Craik, Discovery, structure and biological activities of cyclotides, Adv. Drug Deliv. Rev. 61 (2009) 918-930.

[20] D.C. Ireland, R.J. Clark, N.L. Daly, D.J. Craik, Isolation, sequencing and structureactivity relationships of cyclotides, J. Nat. Prod. 73 (2010) 1610-1622.

[21] Y.L. Chew, E.W. Chan, P.L. Tan, Y.Y. Lim, J. Stanslas, J.K. Goh, Assessment of phytochemical content, polyphenolic composition, antioxidant and antibacterial activities of leguminosae medicinal plants in Peninsular Malaysia, BMC Complement Altern Med. 11 (2011) 12:1-10.

[22] L.R. Badugu, Phytochemical screening, quantitative estimation, total phenolics and total flavonoids, antimicrobial evaluation of Cyamopsis tetragonoloba, Int J. Res. Pharm. Biomed. Sci. 3 (2012) 1139-1142.

[23] A.O. Kabra, G.B. Bairagi, A.S. Mahamuni, R.S. Wanare, In vitro antimicrobia activity and phytochemical analysis of the peels of Citrus medica L, Int. J. Res. Pharm. Biomed. Sci. 3 (2012) 34-37.

[24] N.M. Joseph, S. Sistla, T.K. Dutta, A.S. Badhe, D. Rasitha, S.C. Parija, Reliability of Kirby-Bauer disk diffusion method for detecting meropenem resistance among non-fermenting gram-negative bacilli, Ind. J. Pathol. Microbiol. 54 (2011) 55660.

[25] K. Shanmugapriya, P.S. Saravana, P. Harsha, M. Peer, W. Binnie, A comparative study of antimicrobial potential and phytochemical analysis of Artocarpus heterophyllus and Manilkara zapota seed extracts, J. Pharm. Res. 4 (2011) 2587 $-2589$.

[26] K. Shanmugapriya, P.S. Saravana, P. Harsha, M. Peer, W. Binnie, Antioxidan potential of pepper (Piper nigrum Linn.) leaves and its antimicrobial potential against some pathogenic microbes, Ind. J. Nat. Prod. Resour. 3 (2012) 570 -577.

[27] E.O. Odebiyi, A.H Ramstard, Investigation photochemical screening and antimicrobial screening of extracts of Tetracarpidium conophorum, J. Agric. Chem. Soc. 26 (1978) 1-7.

[28] C. Jennings, J. West, C. Waine, D. Craik, M. Anderson, Biosynthesis and insecticidal properties of plant cyclotides: The cyclic knotted proteins from Oldenlandia affinis, Proc. Natl. Acad. Sci. USA 98 (2001) 10614-10619.

[29] A. Mathur, R. Singh, S. Yousuf, A. Bhardwaj, S.K. Verma, et al., Antifungal activity of some plant extracts against Clinical pathogens, Adv. Appl. Sci. Res. 2(2) (2011) 260-264

[30] S. Manadhar, S. Luitel, R.K. Dahal, In-vitro antimicrobial activity of som medicinal plants against human pathogenic bacteria, J. Trop. Biomed. 2019 (2019) 1895340:1-5

[31] J.G. Sathish, S. Sethu, M.C. Bielsky, L. de Haan, N.S. French, K. Govindappa, B.K. Park, Challenges and approaches for the development of safer immunomodulatory biologics, Nature Rev. Drug Discov. 12(4) (2013) 306324.

[32] M.L. Colgrave, A.G. Poth, Q. Kaas, D.J. Craik, A new "era" for cyclotide sequencing, Biopolym. 94 (2010) 592-601.

[33] K. Shanmugapriya, T. Thayumanavan, L. Alamelu, G. Divya, T.C Hilda, K.S Jamuna, et al, Preliminary phytochemical screening and antimicrobial activity of fresh plant extract of Indian folk medicinal plant, Gnaphalium polycaulon, Int J. Phytomed. 6 (2014) 82-86.

[34] D.C. Ireland, R.J. Clark, N.L. Daly, D.J. Craik, Isolation, sequencing, and structureactivity relationships of cyclotides, J. Nat. Prod. 73 (2010) 1610-1622.

[35] P. Claeson, U. Göransson, S. Johansson, T. Luijendijk, L. Bohlin, Fractionation protocol for the isolation of polypeptides from plant biomass, J. Nat. Prod. 61 (1998) 77-81.

[36] A.G. Poth, M.L. Colgrave, R. Philip, B. Kerenga, N.L. Daly, M.A. Anderson, D.] Craik, Discovery of cyclotides in the fabaceae plant family provides new insights into the cyclization, evolution, and distribution of circular proteins, ACS Chem. Biol. 6 (2011) 345-355.

[37] H.V. Nguyen, J.L. Legras, C. Neuve'glise, C. Gaillardin, Deciphering the Hybridisation history leading to the lager lineage based on the mosaic genomes of Saccharomyces bayanus Strains NBRC1948 and CBS380TM, PLoS ONE 6(10) (2011) e25821:1-19.

[38] B. Upadhay, K.P. Sing, A. Kumar, Ethano-medicinal, phytochemical and antimicrobial studies of Euphorbia tirucalli, J. Phytol. 2 (2010) 65-77.

[39] R.K. Verma, L. Chaurasia, M. Kumar, Antifungal activity of essential oils against selected building fungi, Ind. J. Nat. Prod. Resour. 2 (2011) 448-451. 
[40] A.S. Adekunle, O.C. Adekunle, Preliminary assessment of antimicrobial properties of aqueous extract of plants against infectious diseases, Biol. Med. 1 (2009) 20-24.

[41] M. Urfer, J. Bogdanovic, F. Lo Monte, K. Moehle, K. Zerbe, et al., A peptidomimetic antibiotic targets outer membrane proteins and disrupts selectively the outer membrane in Escherichia coli, J. Biol. Chem. 291(4) (2016) 1921-1932.

[42] S.M. Simonsen, L. Sando, D.C. Ireland, M.L. Colgrave, R. Bharathi, et al., A continent of plant defense peptide diversity: Cyclotides in Australian Hybanthus (Violaceae), Plant Cell 17 (2005) 3176-3189. 